\title{
Characterization of a Partial Sequence Encoding Envelop Protein of HCV-Genotype 4a Egyptian Isolate
}

\author{
Shawky H. ${ }^{1}$, Maghraby A. S. ${ }^{1}$, Solliman M. ${ }^{2}$, El. Mokadem M. T. ${ }^{3}$, \\ Sherif M. M. ${ }^{4}$, Arafa A. ${ }^{1}$, Bahgat M. M. ${ }^{1}$ \\ ${ }^{1}$ The Immunology and Infectious Diseases Laboratory, Therapeutic Chemistry Department, the Center of \\ Excellence for Advanced Sciences, National Research Centre, Dokki, Giza, 12622, Egypt \\ ${ }^{2}$ Vaccines Laboratory, Plant Biotechnology Department, Center of Excellence for Advanced Sciences, National \\ Research Centre, Dokki, Giza, 12622, Egypt \\ ${ }^{3}$ Botany Department, Faculty of Girls, Ain- Shams University \\ ${ }^{4}$ Microbiology and Immunity Department, Faculty of Medicine, Al-Azhar University \\ ${ }^{\S}$ Research Group of Biomarkers for Infection Research, \\ Institute of Experimental Infection Research, TWINCORE Centre for Experimental and Clinical Infection \\ Research, Feodor-Lynen-Straße 7-9 D - 30625 Hannover
}

\begin{abstract}
In this study, RNA isolated from sera of Egyptian HCV-patients was used to amplify a fragment of a M. wt. of $\sim 800 \mathrm{pb}$ corresponding to a partial sequence of the HCV-E2 encoding gene. The amplified fragment was cloned, sequenced and the nucleotide blast analysis of our sequence revealed partial homology with previously published E2-genes of viral isolates from different locations; the highest match (88\%) was annotated with a Japanese isolate suggesting that our herein characterized HCV-E2 partial sequence is a novel one. The impact of HCV-E2 sequence variability will be discussed.
\end{abstract}

\section{Introduction}

About 150 million people are chronically infected with hepatitis $\mathrm{C}$ virus worldwide, and more than 350 000 people die every year from hepatitis C-related liver diseases [1]. Egypt has the highest worldwide prevalence of genotype 4 as the most common in the Middle East and Africa [2]. The HCV genome is a positive-strand, $~ 9.6-\mathrm{kb}$ RNA molecule consisting of a single open reading frame (ORF) flanked by $5^{\prime}$ and $3^{\prime}$ untranslated regions (UTRs). The $5^{\prime}$ UTR contains a highly structured internal ribosome entry site while the $3^{\prime}$ UTR is essential for replication [3, 4]. The HCV-ORF encodes a single polyprotein of $\sim 3000$ amino acids in length and is post translationally processed to produce at least 10 different proteins: the core, envelope proteins (E1-E2), p7 and the non-structural proteins NS2, NS3, NS4A, NS4B, NS5A and NS5B [5, 6, 7]. The envelope glycoprotein genes display some of the highest levels of $\mathrm{HCV}$ genetic heterogeneity, with E2 exhibiting greater variability than E1. The hypervariable region 1 (HVR1) is located at the N-terminus of E2 and this region is the major determinant for strain-specific neutralizing-antibody responses [8]. The rate and nature of nucleotide substitutions within HVR1 during the early stages of infection appear to be correlated with outcome: patients harboring a stable HVR1 quasispecies frequently resolve infection, whilst those with evidence of a rapidly evolving population develop chronic infection. In spite of the high variability of this region there is a strong negative selection against some amino acid substitutions since, at most codons, there is selection for conservative amino acid replacement, pointing to a biological role in the virus life-cycle [9, 10]. E2; one of the possible targets for the development of an effective vaccine, encodes as many as $11 \mathrm{~N}$-linked glycosylation sites, many or all of which may be utilized during the post-translational processing of nascent E1-E2 complexes [11]. Multiple N-linked glycans, in addition to assisting in the folding of antigenically complex proteins, may have other functions, such as masking proteins from reactivity with virus-specific antibodies, facilitating escape from neutralization by antibodies or the complement, and interfering with antigen processing. E2 is thought to mediate attachment to target cells and binds to human CD81, a member of the tetraspanin family of proteins. Interaction of $\mathrm{E} 2$ with $\mathrm{CD} 81$ on $\mathrm{B}$ or $\mathrm{T}$ cells has been reported to result in $\mathrm{B}$-cell aggregation and a lowering of the threshold for T- and B-cell activation $[\mathbf{1 2}, \mathbf{1 3}, \mathbf{1 4}$. The N-terminal 27 residues of E2 (HVR1); aa 384-410, show a very high degree of variation, both within isolates and genotypes, and this portion of the sequence is considered as a leading contributor to disease progression due the emergence of new viral mutants or "quasispecies" induced by the host immune system $[\mathbf{1 5}, \mathbf{1 6}, \mathbf{1 7}]$. This study was designed to amplify HCV-E2 protein encoding sequence from $\mathrm{HCV}$-infected Egyptian patients and compare it to other HCV-envelope sequences from different geographical settings. 


\subsection{Human Sera}

\section{Materials and Methods}

Blood samples were collected from infected Egyptian patients with HCV who were examined at the Medical Unit of the National Research Center. Additional blood samples were collected from humans with no history of liver diseases or infections and used as negative control. Both were centrifuged at 14,000xg, sera were separated, divided into aliquots and stored at $-80{ }^{\circ} \mathrm{C}$ until used for viral RNA extraction, measuring liver enzymes and detecting of anti-HCV antibodies (Axium; Florida, USA).

\subsection{Approval of the Ethical Committee}

Collection of human blood samples was approved by the Medical Ethical Committee of the National Research Center in Egypt according to the ethical guidelines approved by the Ethical Committee of the Federal Legislation and ethical guidelines of the National Institutes of Health in the USA.

\subsection{Amplification of $\mathrm{HCV}-\mathrm{E} 2 \mathrm{Gene}$}

Viral RNA was extracted from sera of HCV infected patients according to the manufacturer's instructions, (Qiagen, Hilden, Germany). The HCV-E2 encoding sequence was amplified using the listed primers in (Table 1) in either a single round or nested reverse transcriptase polymerase chain reaction (RTPCR) and the RevertAid premium RT (Thermofisher Scientific; USA). The RT program included 60 min at 50 ${ }^{\circ} \mathrm{C}$ followed by enzyme deactivation at $85^{\circ} \mathrm{C}$ for $5 \mathrm{~min}$. The first PCR program included 35 cycles each of 30 seconds (s) at $94^{\circ} \mathrm{C}, 45$ seconds at $54^{\circ} \mathrm{C}$ and 2 min at $72^{\circ} \mathrm{C}$ using a DreamTaq DNA polymerase (Thermofisher Scientific, USA), followed by a final extension at $72{ }^{\circ} \mathrm{C}$ for $10 \mathrm{~min}$. The PCR product was used in the nested PCR and the program included 35 cycles of $30 \mathrm{~s}$ at $94^{\circ} \mathrm{C}, 30 \mathrm{~s}$ at $58^{\circ} \mathrm{C}, 1 \mathrm{~min}$ at $72^{\circ} \mathrm{C}$ and a final extension of 72 ${ }^{\circ} \mathrm{C}$ for $10 \mathrm{~min}$. PCR products were resolved by electrophoresis on $1 \%$ agarose gels, gel slices carrying the amplified fragments were cut and subjected for DNA extraction (Gel cleaning kit; Thermofisher Scientific, USA).

\subsection{Cloning, Plasmid Purification and Sequencing}

The purified envelope fragment was first cloned into the pSC-TA plasmid (Stratagen) according to the user manual and the generated construct (pSC-E2) was used to transform the DH5 $\alpha-E$. coli competent cells. Successful cloning was confirmed by colony PCR on grown bacteria on LB/ampicillin agar plates. PCR-positive colonies were subjected to small-scale plasmid preparation using the GeneJet plasmid DNA miniprep kit (Thermofisher Scientific, USA), the purified plasmid was subjected to automated sequencing from both directions using the HCV-E2 sequence specific forward (F) and reverse (R) primers. The obtained sequences were aligned to the previously published sequences in the GenBank using the basic nucleotide blast application. Construction of a neighbor-joining phylogenetic tree was done using the Bioedit software (http://www.mbio.ncsu.edu/BioEdit/ bioedit.html).

\section{Results \& Discussion}

\subsection{Successful Amplification and Cloning of the Encoding Fragment for the HCV-E2 Protein}

A fragment of a M. wt. of $\sim 800$ pb corresponding to a partial sequence of the HCV-E2 encoding gene was visualized upon subjecting extracted RNA from HCV-infected human sera to RT-PCR (Fig. 1.A). Successful amplification of HCV-E2 fragment was first confirmed by internal PCR that resulted in a shorter fragment of $660 \mathrm{pb}$ when as expected molecular weight predicted from the published sequence of HCV.Ed43 (Accession NO.: Y11604) (Fig. 1.B). Moreover, successful cloning to pSC-TA vector was verified when the same parent fragment $(800 \mathrm{bp})$ was detected by direct PCR on transformed bacteria with the construct carrying such a fragment (Fig 2).

\subsection{Homology of the Obtained Sequence with Previously Published HCV-E2 Gene Sequences from Various Geographical Settings}

Nucleotide blast analysis (ncbi.nlm.nih.gov) of our HCV-E2 partial sequence revealed partial homology with previously published E2-genes of viral isolates from different locations such as Egypt, Japan, USA, UK and others.The highest extent of homology (88\%) was annotated with the sequence of hepatitis C virus subtype 4a genomic RNA, complete genome, isolate: HCV genotype 4a-KM (AB795432.1, TsukiyamaKohara, K. and Michinori Kohara, 2013 (unpublished)), which further confirms the successful amplification of the HCV-E2 fragment and strongly suggest a correlation between such sequence variation and the resistance of Egyptian HCV $4 \mathrm{a}$-infected patients to any HCV therapy including the novel ones containing the protease inhibitors [18]. The descending order of the homology of our HCV-E2 partial nucleotide sequence with previously published ones is presented in Table (2). Nucleotide sequence-based phylogenetic tree is demonstrated in (Fig. 3). 


\section{Conclusion}

Both partial homology and unique features of our newly characterized HCV-E2 sequence compared to previously published HCV-envelope sequences might be among the reasons for the poor response of HCV-4a to effective anti-HCV therapy against other genotypes of the virus.

\section{Acknowledgment}

The authors acknowledge the National Research Centre (NRC) of Egypt for providing all needed facilities and logistics for the work. We are also grateful to Prof. Dr. Sohair Fawzy and Dr. Hossam Eid Gewaid for providing the $\mathrm{HCV}$ - patient's sera.
[1]. WHO. WHO fact sheet: HCV vaccines
number 164, 2012. Available from: http://www.who.int/mediacentre/factsheets/fs164/en/Updated July 2013.

[2]. $\quad$ Abdelwahab S.F., Hashem M., Galal I., Sobhy M., Abdel-Ghaffar T.S., Galal G., Mikhail N., El-Kamary S.S., Waked I. and Strickland G.T. (2013). Incidence of hepatitis C virus infection among Egyptian healthcare workers at high risk of infection. J Clin. Virol. 57 (1): 24-8.

[3]. Friebe P. and Bartenschlager R. (2002). Genetic analysis of sequences in the $3^{\prime}$ non-translated region of hepatitis C virus that are important for RNA replication. J. Virol. 76: 5326 - 38.

[4]. Yi M. and Lemon S. M. (2003). Structure-function analysis of the 3' stem-loop of hepatitis C virus genomic RNA and its role in viral RNA replication. RNA, 9: 331- 45.

[5]. Bartenschlager R. and Lohmann V. (2000). Replication of hepatitis C virus. J. Gen. Virol. 81: 1631- 48.

[6]. Bradley D.W. (2000). Studies of non -A, non -B hepatitis and characterization of the hepatitis C virus in chimpanzees. Curr. Top. Microbiol. Immunol. 242: 1-23.

[7]. Reed K.E. and Rice C.M. (2000). Overview of hepatitis C virus genome structure, polyprotein processing, and protein properties. Curr. Top. Microbiol. Immunol, 242: 55-84.

[8]. Logvinoff C., Major M.E., Oldach D., Heyward S., Talal A., Balfe P., Feinstone S.M., Alter H., Rice C.M. and McKeating J.A. (2004). Neutralizing antibody response during acute and chronic hepatitis C virus infection. Proc Natl Acad Sci USA, 101: $10149-54$.

[9]. Sobolev B.N., Poroikov V.V., Olenina L.V., Kolesanova E.F., Archakov A.I. (2000). Comparative analysis of amino acid sequences from envelope proteins isolated from different hepatitis $\mathrm{C}$ virus variants: possible role of conservative and variable regions. J Viral Hepat, 7: $368-74$

[10]. Song C. and Yu-ming W. (2007). Evolutionary study of hepatitis C virus envelope genes during primary infection. Chin Med J., 120: $2174-80$.

[11]. Dubuisson J., Hsu H., Cheung R., Greenberg H., Russel D., and Rice C. (1994). Formation and intracellular localization of hepatitis C virus envelope glycoprotein complexes expressed by recombinant vaccinia and Sindbis viruses. J. Virol, 68: 6147-6160.

[12]. Levy S., Todd S., and Maecker H. (1998). CD81 (TAPA-1): a molecule involved in signal transduction and cell adhesion in the immune system. Annu. Rev. Immunol, 16: 89-109.

[13]. Wack A., Soldaini E., Tseng C., Nuti S., Klimpel G., and Abrignani S. (2001). Binding of the hepatitis C virus envelope protein E2 to CD81 provides co-stimulatory signal for human T cells. Eur. J. Immunol, 31:166 -75.

[14]. Genovese D., Dettori S., Argentini C., Villano U., Chionne P., Angelico M. and Rapicetta M. P. (2005). Molecular Epidemiology of Hepatitis C Virus Genotype 4 Isolates in Egypt and Analysis of the Variability of Envelope Proteins E1 and E2 in Patients with Chronic Hepatitis. J. Clin. Microbiol, 43: 1902-9.

[15]. Mizushima H., Hijikata M., Asabe S., Hirota M., Kimura K., Shimotohno K. (1994). Two hepatitis C virus glycoprotein E2 products with different C termini. J. Virol, 68: 6215-22.

[16]. Farci P., Shimoda A., Coiana A., Diaz G., Peddis G., Melpolder J., Strazzera A., Chien D., Munoz S., Balestrieri A., Purcell R. and Alter H. (2002). The outcome of acute hepatitis $C$ predicted by the evolution of the viral quasispecies. Science, 88: 339-44.

[17]. Keck Z., De Beeck A., Hadlock K., Xia J., Li T., Dubuisson J. and Foung S. (2004). Hepatitis C Virus E2 Has Three Immunogenic Domains Containing Conformational Epitopes with Distinct Properties and Biological Functions. J. Virol, 78: 922432.

[18]. El-Khattib A.A., Abdelhakam S.M., Ghoraba D.M., Ibrahim W. A. and Sayed M.M. (2012). Outcome of antiviral therapy in Egyptian hepatitis C virus (HCV) genotype 4 patients with advanced liver fibrosis. Eur. J. Inter. Med., 23: e34-e35.

[19]. Timm J., Neukamm M., Kuntzen T., Kim A.Y., Chung R.T., Brander C., Lauer G.M., Walker $\quad$ B.D. and Allen T.M. (2007). Characterization of Full-Length Hepatitis C Virus Genotype 4 sequences. J. Viral Hepat, 14 (5): 330-7.

[20]. Lavillette D., Tarr A.W., Voisset C., Donot P., Bartosch B., Bain C., Patel A.H., Dubuisson J., Ball J.K. and Cosset F.L. (2005). Characterization of host-range and cell entry properties of the major genotypes and subtypes of Hepatitis C Virus. Hepatology, 41 (2): 265-74.

[21]. Franco S., Tural C., Clotet B. and Martinez M.A. (2007). Complete nucleotide sequence of genotype 4 Hepatitis C Viruses isolated From patients co-infected with human immunodeficiency virus type 1. Virus Res, 123 (2): 161-9.

[22]. Broering T.J., Garrity K.A., Boatright N.K., Sloan S.E., Sandor F., Thomas W.D., Szabo G., $\quad$ Finberg R.W., Ambrosino D.M. and Babcock G.J. (2009). Identification and characterization of broadly neutralizing human monoclonal antibodies directed against the E2 envelope glycoprotein of Hepatitis C Virus. J. Virol, 83 (23): 12473-82.

[23]. Gray R.R., Strickland S.L., Veras N.M., Goodenow M.M., Pybus O.G., Lemon S.M., Fried M.W., Nelson D.R., Salemi M. (2012). Unexpected Maintenance of Hepatitis C Viral Diversity following Liver Transplantation. J. Virol, 86 (16), 8432-39.

[24]. Lu L., Li C., Yuan J., Lu T., Okamoto H., Murphy D.G. (2013). Full-length genome sequences of five hepatitis C virus isolates representing subtypes $3 \mathrm{~g}, 3 \mathrm{~h}, 3 \mathrm{i}$ and $3 \mathrm{k}$, and a unique genotype 3 variant. J. Gen. Virol, 94 (PT 3), 543-8.

[25]. Xia X., Lu L., Tee K.K., Zhao W., Wu J., Yu J., Li X., Lin Y., Mukhtar M.M., Hagedorn C.H., Takebe Y. (2008). The unique HCV genotype distribution and the discovery of a novel subtype 6u among IDUs co-infected with HIV-1 in Yunnan, China. J. Med. Virol, 80 (7): 1142-52. 
[26]. Stuyver L., vanArnhem W., Wyseur A., Hernandez F., Delaporte E., Maertens G. (1994). Classification of hepatitis C viruses based on phylogenetic analysis of the envelope 1 and nonstructural 5B regions and identification of five additional subtypes. Proc. Natl. Acad. Sci. USA, 91 (21), 10134-38.

\section{Figures And Tables}

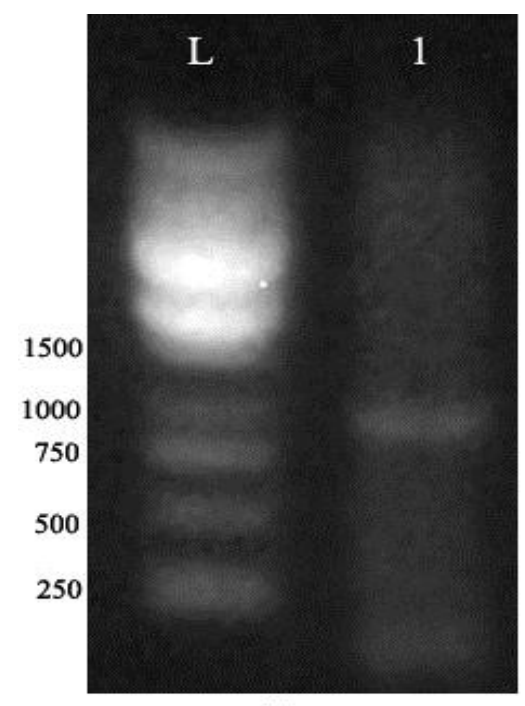

(A)

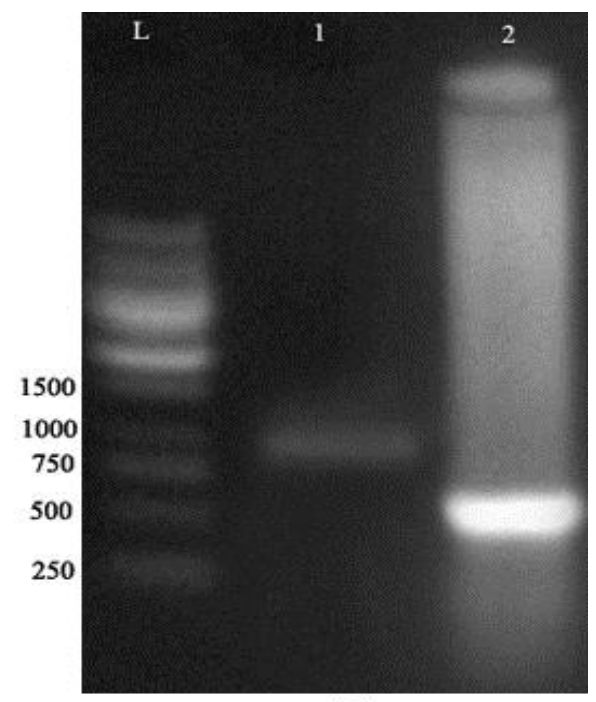

(B)

Fig. (1): Amplification of HCV-E2 fragments. Fig (1A) shows the PCR product following RT-PCR. A homogenous band of $\sim 800 \mathrm{pb}$ was detected at the expected M.wt. Fig (1B) shows the nested PCR amplification of smaller band of $\sim 660 \mathrm{pb}$ (lane 2) when the purified HCV-E2 fragment (lane 1) was used as template. Electrophoresis was carried out on $1 \%$ agarose gel and a $1 \mathrm{~kb}$ DNA ladder was run on the same gel (lane L).

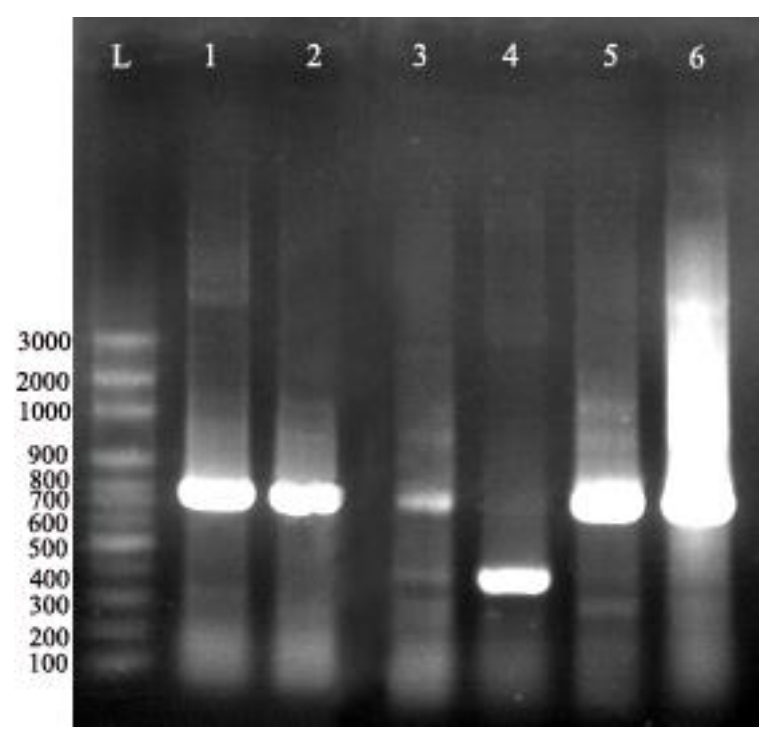

Fig. (2): Amplification products obtained from direct PCR on individual E. coli BL21 (DE3) colonies transformed with the pSC-A constructs into which the HCV-E2-encoding sequence was cloned using insertspecific primers. Specific bands of a M.wt. 800 bp were visualized in 4 out of 6 tested colonies reflecting high cloning efficiency. Electrophoresis was carried out on $1 \%$ agarose gel and a $1 \mathrm{~kb}$ DNA ladder was run on the same gel (lane L). 


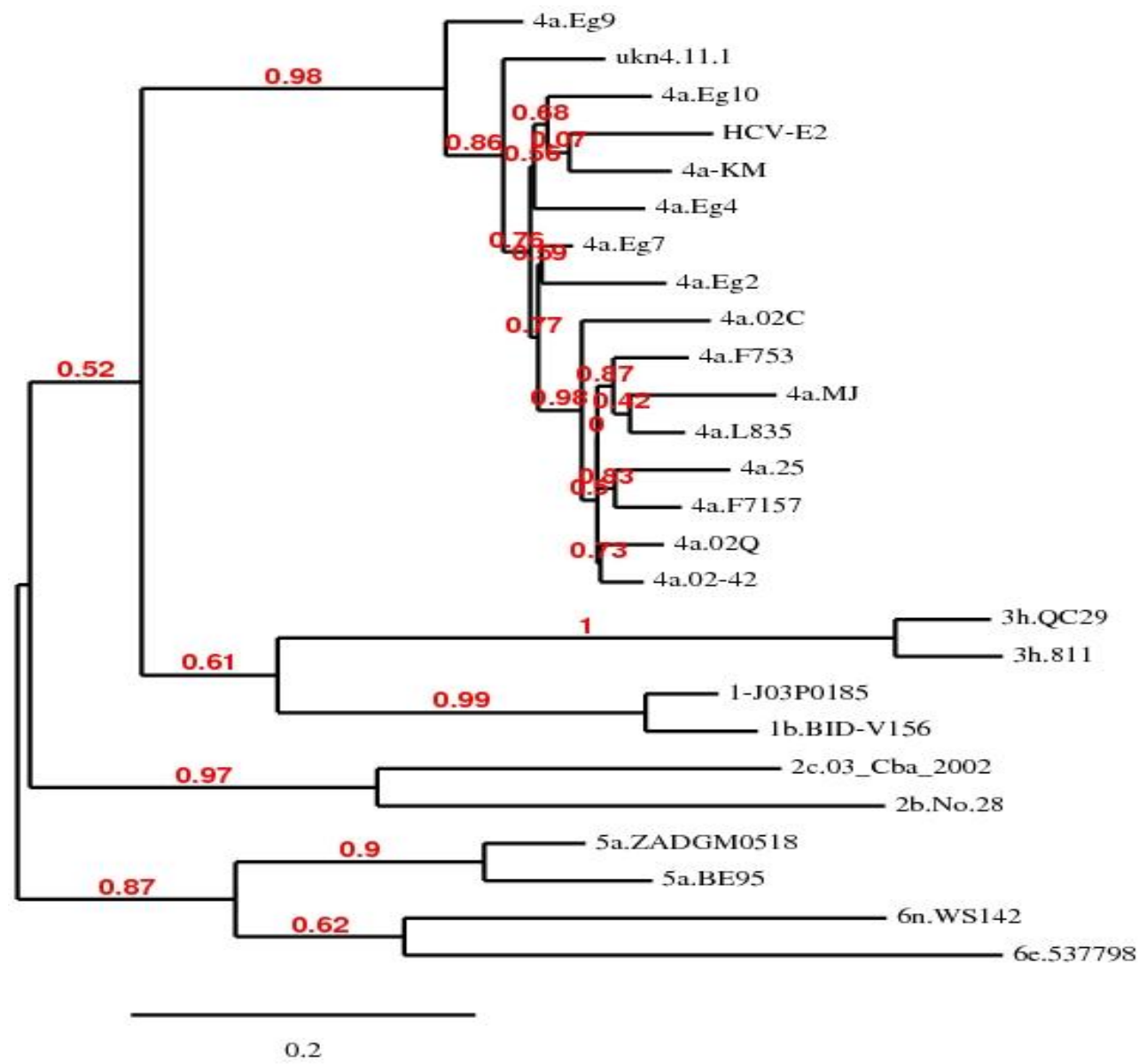

Fig. (3): Phylogenetic comparison of HCV-E2 sequence from Egyptian isolate with published ones with highest degree of homology.

\begin{tabular}{|c|c|c|c|c|c|c|}
\hline Description & Country & $\begin{array}{l}\text { Total } \\
\text { Score }\end{array}$ & $\begin{array}{l}\text { Max } \\
\text { Ident }\end{array}$ & Accession & $\begin{array}{l}\text { Year Of } \\
\text { Submission }\end{array}$ & Publication \\
\hline $\begin{array}{l}\text { Hepatitis C virus subtype } 4 a \text { genomic } \\
\text { RNA, complete genome, isolate: } \\
\text { HCVgenotype } 4 a-K M\end{array}$ & Japan & 514 & $88 \%$ & AB795432 & 2013 & - \\
\hline $\begin{array}{l}\text { Hepatitis } \mathrm{C} \text { virus isolate } \mathrm{Eg} 7 \\
\text { polyprotein gene, partial cds }\end{array}$ & Egypt & 483 & $86 \%$ & DQ988076 & 2007 & - \\
\hline $\begin{array}{l}\text { Hepatitis } C \text { virus isolate } \mathrm{Eg} 4 \\
\text { polyprotein gene, partial cds }\end{array}$ & Egypt & 466 & $86 \%$ & DQ988075 & 2007 & - \\
\hline $\begin{array}{l}\text { Hepatitis } C \text { virus subtype } 4 a \text { isolate } \\
02-42 \text { polyprotein gene, complete cds }\end{array}$ & USA & 460 & $87 \%$ & DQ418783 & 2007 & [19] \\
\hline $\begin{array}{l}\text { Hepatitis } \mathrm{C} \text { virus isolate } \mathrm{Eg} 10 \\
\text { polyprotein gene, partial cds }\end{array}$ & Egypt & 455 & $85 \%$ & DQ988078 & 2007 & - \\
\hline $\begin{array}{l}\text { Hepatitis C virus subtype } 4 \mathrm{a} \text { isolate } \\
\text { L835 polyprotein gene, complete cds }\end{array}$ & USA & 448 & $86 \%$ & DQ418789 & 2007 & [19] \\
\hline $\begin{array}{l}\text { Synthetic construct clone ukn } 4.11 .1 \\
\text { envelope protein gene, complete cds }\end{array}$ & UK & 448 & $85 \%$ & AY734986 & 2007 & {$[20]$} \\
\hline $\begin{array}{l}\text { Hepatitis } \mathrm{C} \text { virus isolate } \mathrm{Eg} 2 \\
\text { polyprotein gene, partial cds }\end{array}$ & Egypt & 446 & $85 \%$ & DQ988073 & 2007 & - \\
\hline $\begin{array}{l}\text { Hepatitis } \mathrm{C} \text { virus isolate } 02 \mathrm{Q} \\
\text { polyprotein gene, partial cds }\end{array}$ & USA & 442 & $86 \%$ & DQ418785 & 2007 & [19] \\
\hline $\begin{array}{l}\text { Hepatitis } C \text { virus subtype } 4 \mathrm{a} \text { isolate } 25 \\
\text { polyprotein gene, complete cds }\end{array}$ & SP & 436 & $85 \%$ & DQ516084 & 2007 & [21] \\
\hline
\end{tabular}




\begin{tabular}{|c|c|c|c|c|c|c|}
\hline $\begin{array}{l}\text { Hepatitis } \mathrm{C} \text { virus subtype } 4 \mathrm{a} \text { isolate } \\
02 \mathrm{C} \text { polyprotein gene, complete cds }\end{array}$ & USA & 433 & $85 \%$ & DQ418784 & 2007 & [19] \\
\hline $\begin{array}{l}\text { Hepatitis } C \text { virus subtype } 4 \mathrm{a} \text { isolate } \\
\text { F7157 polyprotein gene, complete cds }\end{array}$ & USA & 425 & $86 \%$ & DQ418788 & 2007 & [19] \\
\hline $\begin{array}{l}\text { Hepatitis C virus isolate } \mathrm{Eg} 9 \\
\text { polyprotein gene, partial cds }\end{array}$ & Egypt & 412 & $84 \%$ & DQ988077 & 2007 & - \\
\hline $\begin{array}{l}\text { Hepatitis C virus subtype } 4 \mathrm{a} \text { isolate } \\
\text { F753 polyprotein gene, complete cds }\end{array}$ & USA & 411 & $84 \%$ & DQ418787 & 2007 & [19] \\
\hline $\begin{array}{l}\text { Hepatitis C virus isolate } 4 \mathrm{a}-\mathrm{MJ} \\
\text { polyprotein gene, partial cds }\end{array}$ & USA & 409 & $84 \%$ & GQ379230 & 2009 & [22] \\
\hline $\begin{array}{l}\text { Hepatitis C virus (1) isolate J03P0185 } \\
\text { envelope glycoprotein (env) gene, } \\
\text { partial cds }\end{array}$ & USA & 304 & $73 \%$ & JQ064300 & 2011 & [23] \\
\hline \begin{tabular}{l} 
Hepatitis C virus subtype $1 \mathrm{~b}$ isolate \\
HCV-1b/US/BID- \\
V156/2004,complete \\
\multicolumn{2}{c}{ complete genome }
\end{tabular} & USA & 291 & $73 \%$ & EU155226 & 2009 & - \\
\hline $\begin{array}{l}\text { Hepatitis C virus }(2 \mathrm{c}) \text { isolate } \\
\text { 03_Cba_2002 polyprotein gene, partial } \\
\text { cds }\end{array}$ & Argentina & 285 & $72 \%$ & JF511047 & 2011 & - \\
\hline $\begin{array}{l}\text { Hepatitis C virus (3h) isolate QC29, } \\
\text { complete genome }\end{array}$ & Canada & 277 & $70 \%$ & JF735121 & 2013 & [24] \\
\hline $\begin{array}{l}\text { Hepatitis C virus (3h) isolate } 811 \text {, } \\
\text { complete genome }\end{array}$ & Somalia & 277 & $70 \%$ & JF735126 & 2013 & - \\
\hline 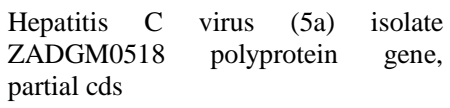 & $\begin{array}{l}\text { South } \\
\text { Africa }\end{array}$ & 272 & $70 \%$ & KC767832 & 2013 & - \\
\hline $\begin{array}{l}\text { Hepatitis C virus (6n) isolate WS142 } \\
\text { polyprotein gene, partial cds }\end{array}$ & China & 271 & $69 \%$ & EU119974 & 2008 & [25] \\
\hline 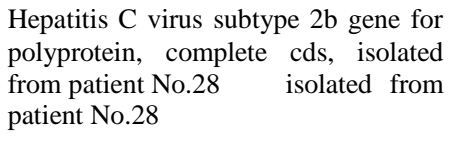 & Japan & 269 & $70 \%$ & AB661432 & 2011 & - \\
\hline $\begin{array}{l}\text { Hepatitis C virus }(6 \mathrm{e}) \text { isolate } 537798 \\
\text { polyprotein precursor, gene, complete } \\
\text { cds }\end{array}$ & USA & 263 & $69 \%$ & EU408326 & 2009 & - \\
\hline $\begin{array}{l}\text { Hepatitis C virus type 5a (BE95) } \\
\text { envelope protein (E1) gene, partial } \\
\text { cds; envelope protein (E2) gene, } \\
\text { complete cds }\end{array}$ & Belgium & 258 & $69 \%$ & L29578 & 1995 & [26] \\
\hline
\end{tabular}

\section{Table (1) list of primers used in gene amplification and screening}

Table (2): Homology results of nucleotide sequence of our HCV-E2 gene to published HCV-envelope

\begin{tabular}{|l|l|l|l|}
\hline & Primer ID & Primer sequence & Nucleotide position \\
\hline 1 & Outer sense & 5'GGCTCTTGTCCCCCGTGGC3' $^{\prime}$ & $566-588$ \\
\hline 2 & EF1 & 5'CACTGGACCACCCAGGATTGCA3' & $1171-1196$ \\
\hline 3 & E2F2 & 5'CACTGGGGTGTCCTCGTGGG 3' & $1228-1253$ \\
\hline 4 & E2R1 & 5'TGAACAGTACCGGGTTCACCAA 3' & $1947-1967$ \\
\hline 5 & E2R2 & 5'TGGATGAACAGTACCGGGTTCA3' & $1942-1963$ \\
\hline
\end{tabular}

sequences in GenBank database 